\title{
Synthesis and application of a composite NaA zeolite/gamma-alumina membrane for oil-water separation process
}

\author{
(Síntese e aplicação de uma membrana compósita zeólita \\ NaA/gama-alumina para o processo de separação de óleo/água)
}

\author{
T. L.A.Barbosa ${ }^{1}$, F. M. N. Silva ${ }^{1}$, A. S. Barbosa ${ }^{1}$, E. G. Lima ${ }^{1}$, M. G. F. Rodrigues ${ }^{1 *}$ \\ ${ }^{1}$ Universidade Federal de Campina Grande, Unidade Acadêmica de Engenharia Química, \\ Av. Aprígio Veloso 882, 58429-970, Campina Grande, PB, Brazil
}

\begin{abstract}
This study proposed the development of an efficient membrane composed of zeolite-alumina to be used for water-oil separation of wastewater effluents contaminated by oil extraction processes. The efforts made to care for the environment and to decontaminate bodies of water are extremely valuable and constantly being updated. Little research has been done on this subject and this study contributed to remedying this lack. Membrane technology is a reasonable alternative to conventional procedures if economics and eco-sustainability are considered. The objective of this study was to examine the performance of a composite membrane produced through mechanical mixing. The potential of the composite membrane (NaA zeolite/gama-alumina) to separate oil-water emulsions was tested. The results obtained demonstrated that the composite membrane is an excellent alternative for the oil/water emulsion separation process; the membranes are efficient and low-cost alternatives for treating oily wastewater.
\end{abstract}

Keywords: composite membrane, zeolite NaA, gamma-alumina, oily wastewater, oil-water emulsion.

\section{Resumo}

Este estudo propôs o desenvolvimento de uma membrana eficiente composta por zeólita-alumina a ser utilizada na separação óleol água de efluentes contaminados por processos de extração de óleo. Os esforços feitos para cuidar do meio ambiente e descontaminar reservas de água são extremamente valiosos e constantemente atualizados. Pouca pesquisa foi feita sobre este assunto e este estudo contribuiu para remediar essa falta. A tecnologia de membrana é uma alternativa razoável para procedimentos convencionais, se economia e ecossustentabilidade forem consideradas. O objetivo deste estudo foi examinar o desempenho da membrana compósita produzida através de mistura mecânica. O potencial da membrana compósita (zeólita NaA/gama-alumina) para separar as emulsões óleo/água foi testado. Os resultados obtidos demonstraram que a membrana compósita é uma excelente alternativa para o processo de separação da emulsão óleo/água; as membranas são alternativas eficientes e de baixo custo para o tratamento de efluentes oleosos.

Palavras-chave: membrana compósita, zeólita NaA, gama-alumina, águas residuais oleosas, emulsão de óleo/água.

\section{INTRODUCTION}

During drilling and production activities, considerable waste is generated that must be treated. Waste treatment seeks to lower the potential hazards associated with waste by reducing its toxicity, minimizing its volume, and/or altering its state so that it is suitable for specific disposal methods. Treatment is required for many diverse types of waste prior to final disposal, and various treatment methods are available for most wastes, but not all methods can be used for all waste streams. These different treatment methods may vary considerably in both effectiveness and cost [1-3]. Traditional methods of managing wastewater

*meiry.rodrigues@ufcg.edu.br

Dhttps://orcid.org/0000-0003-2258-4230 do not adequately satisfy petroleum industry requirements for treatment in compliance with discharge and reuse standards [3-5]. Thus, there is a substantial need for new innovative membrane technologies. The existing literature regarding these processes and recent advancements in membrane technology applications in the petroleum industry are insufficient [4-8]. Inorganic membranes exhibit unique characteristics that make them attractive for use in the separation processes, such as mechanical and thermal stability. The membranes also contain some materials that have been applied as chemical adsorbents [9-12]. Over the past few years, inorganic membrane separation technology has seen accelerated growth and innovation [13]. Various membrane separation processes have been developed, and new processes are continually being studied in both academia and the industry.

Zeolite membranes are porous and thermally stable, acidic 
or basic in nature, and present hydrophilic or organophilic properties [14-23]. In comparison with other procedures, the results of green membrane technology generate effluents of good quality. The operation is simple and requires only a small area to function, without the need for additional chemicals, thereby reducing the risk of incrustation [24]. Certainly, membrane technology is a reasonable alternative to conventional procedures, when taking into account economics and eco-sustainability. Polycrystalline Linde Type A (LTA) zeolites are intensely hydrophilic and have a central pore of $\sim 4.2 \AA$ [14]. Single LTA zeolite nanoparticles have shown high rejection of small molecules in gas separations [25]. These properties give zeolites significant potential for aqueous membrane separation applications. The NaA zeolite/ $\alpha$-alumina membrane was evaluated for the process of treatment of oil-contaminated water [26]. NaA zeolite microfiltration membranes were synthesized on an $\alpha$-alumina tube by the hydrothermal synthesis method. The results were $99 \%$ of oil rejection for the membrane $\mathrm{NaA}$ zeolite/ $\alpha$-alumina. Our research group has published some papers on the production of zeolite membranes and composite membranes [27-39]. Zhan et al. [40] demonstrated novel thermally and chemically stable composite membranes consisting of halloysite nanotubes (HNTs) intercalated with graphene oxide (GO) coating on porous poly(arylene ether nitrile) (PEN) nanofibrous mat, which were prepared by controlled assembly of HNTs intercalated GO (skin layer) onto the surface of electrospun PEN nanofibrous mats (supporting layer) and further mussel-inspired polydopamine coating. The resulting composite membranes exhibited a high preferable rejection ratio (more than $99.0 \%$ ) and remarkable antifouling performance for various oil/water emulsions. Furthermore, flexible channel control of the skin layer by intercalation of HNTs, porous PEN supporting layer, and super-wetting property endowed the composite membranes with high permeate flux $\left(1130.56 \mathrm{~L} / \mathrm{m}^{2} . h\right)$ [40]. Yang et al. [41] studied hydrophilic modification of PVDF membrane processed by a mussel-inspired method. Multiwall carbon nanotubes (MWCNTs) were functionalized by grafting 3-aminopropyltriethoxysilane (APTES) and then directly decorated on PVDF membrane surface by dopamine copolymerization. The modified membranes could be applied to separate different kinds of oil-in-water emulsions with high permeate flux (about $900 \mathrm{~L} / \mathrm{m}^{2}$.h under $0.09 \mathrm{MPa}$ ) and ultrahigh oil rejection ratio (nearly 99\%). More importantly, the as-prepared superhydrophilic PVDF membranes showed durable oil-fouling repellency, which could be easily recycled with a recovery of flux ratio up to $90 \%$.

The literature is scarce regarding the use of zeolitic membranes for oil-water removal. In this regard, it is interesting to study the use of these membranes for the water separation process. In order to achieve an easy and effective synthesis of the composite membrane (NaA zeolite/ gamma-alumina), the mechanical mixing method was used. This method is advantageous because of its relative simplicity, low operating cost, and low energy consumption requirements. The composite membrane produced through mechanical mixing can be completed in less than $4 \mathrm{~h}$ after the fabrication of the materials. In light of the growth potential, the composite membrane ( $\mathrm{NaA}$ zeolite/gamma-alumina) is expected to be used in processes that separate oil from water.

\section{MATERIALS AND METHODS}

Materials: aluminum sulfate $\left[\mathrm{Al}_{2}\left(\mathrm{SO}_{4}\right)_{3} \cdot 18 \mathrm{H}_{2} \mathrm{O}\right]$ P.A., sodium metasilicate $\left(\mathrm{Na}_{2} \mathrm{SiO}_{3} .5 \mathrm{H}_{2} \mathrm{O}\right)$, sodium hydroxide pellets (Prolabo, 98\%), sodium aluminate $\left(\mathrm{Na}_{2} \mathrm{O}\right.$. $\mathrm{Al}_{2} \mathrm{O}_{3} \cdot 3 \mathrm{H}_{2} \mathrm{O}$, Riedel-de Haen), deionized water, oleic acid, PABA (para-aminobenzoic acid), ethanol $\left(\mathrm{C}_{2} \mathrm{H}_{6} \mathrm{O}\right.$, Vetec, 99\%), and chloroform P.A. (Synth) were used.

Preparation of gamma-alumina (powder): the thermal decomposition of aluminum sulfate was carried out in a muffle furnace at $1000{ }^{\circ} \mathrm{C}$ for $2 \mathrm{~h}$ using a heating rate of 5 ${ }^{\circ} \mathrm{C} /$ min to produce gamma-alumina crystal phase [32].

Preparation of ceramic membrane: the ceramic membrane (asymmetric support of gamma-alumina) was manufactured by using the uniaxial dry compaction method. A mixture of alumina with additives in a total of $200 \mathrm{~mL}$ of dispersion with the composition of $40 \%$ of produced gamma-alumina, $0.2 \%$ of PABA (dissolved in ethanol), $0.5 \%$ oleic acid (lubricant), and $59.3 \%$ ethyl alcohol was prepared. After $1 \mathrm{~h}$ milling, the mixture was transferred to a reservoir and then dried at $60^{\circ} \mathrm{C}$ for $24 \mathrm{~h} .3 \mathrm{~g}$ of the material was inserted into a stainless steel mold and pressed for $2 \mathrm{~min}$ with 4 ton. In order to increase the mechanical strength, the ceramic membrane was sintered in air for $2 \mathrm{~h}$ at $700{ }^{\circ} \mathrm{C}$; the heating rate was $5{ }^{\circ} \mathrm{C} / \mathrm{min}$ from room temperature to $700^{\circ} \mathrm{C}$. A ceramic flat membrane (gamma-alumina) was produced with a diameter of $26.6 \mathrm{~mm}$ and a thickness of $3.6 \mathrm{~mm}$ [31].

Synthesis of NaA zeolite: zeolite $\mathrm{NaA}$ was synthesized by hydrothermal synthesis based on the procedure reported in [42] with some modifications. The preparation consisted of the following steps: 1) $0.723 \mathrm{~g}$ of sodium hydroxide was added to deionized water, then mixed until $\mathrm{NaOH}$ was completely dissolved; afterward, the solution was divided into two equal volumes in polypropylene bottles; 2 ) in a half of (1), $8.258 \mathrm{~g}$ of sodium aluminate was added and then mixed in a capped bottle until the mixture became clear; 3 ) in the second half of (1), $15.48 \mathrm{~g}$ of sodium metasilicate was added and also mixed in a capped bottle until clear; 4) the silicate solution (2) was quickly poured into the aluminate solution (3) to form a thick gel. Finally, the resultant gel was stored in a sealed autoclave. After crystallization at $100{ }^{\circ} \mathrm{C}$ for $4 \mathrm{~h}$, the final product was washed, then dried in air at $100{ }^{\circ} \mathrm{C}$ for $24 \mathrm{~h}$. The sample was synthesized with a molar composition of $4.62 \mathrm{Na}_{2} \mathrm{O}: 1 \mathrm{Al}_{2} \mathrm{O}_{3}: 6 \mathrm{SiO}_{2}: 180 \mathrm{H}_{2} \mathrm{O}$.

Preparation of composite membrane of NaA zeolitel gamma-alumina: the composite membrane was manufactured by the mechanical mixing of gamma-alumina and $\mathrm{NaA}$ zeolite. The ratio of $50 \%(\mathrm{w} / \mathrm{w})$ gamma-alumina/ $\mathrm{NaA}$ zeolite was used. The mixture was poured in a stainless steel mold and pressed with 4 ton for $2 \mathrm{~min}$. After that, the membrane was submitted to a heat treatment at $550{ }^{\circ} \mathrm{C}$ for $4 \mathrm{~h}$ to improve 
its mechanical strength. After these steps, it was obtained a planar composite membrane (NaA/gamma-alumina) with a diameter of $26.6 \mathrm{~mm}$ and a thickness of $3.6 \mathrm{~mm}$.

Characterization: X-ray diffraction: XRD analysis of the samples was performed using a Shimadzu XRD 6000 diffractometer with $\mathrm{CuK} \alpha$ radiation, operated at $30 \mathrm{~mA}$ and $40 \mathrm{kV}$, with a goniometer velocity of $2 \% \mathrm{~min}$ and a step of $0.02^{\circ}$ in the scanning range of $2 \theta$ from $2^{\circ}$ to $50^{\circ}$. Nitrogen adsorption-desorption: $\quad \mathrm{N}_{2}$ gas adsorption/desorption isotherms were obtained at $-196{ }^{\circ} \mathrm{C}$ using a Micrometrics ASAP 2020 equipment in the range of relative pressure $\left(\mathrm{P} / \mathrm{P}_{0}\right)$ between 0.02 and 1.0. The values of the average pore diameter and surface area $\left(\mathrm{S}_{\mathrm{BET}}\right)$ were obtained by the BET method and the pore sizes and total pore volumes were determined by the Barrett-Joyner-Halenda (BJH) method from desorption branches of the isotherms. Scanning electron microscopy: SEM images were obtained with a Philips XL 30 microscope. Mercury porosimetry: it was performed in a mercury porosimeter, Micromeritics Autopore IV 9500 V1.05. Mechanical strength: the tensile strength of the ceramic support (gamma-alumina) was determined by the diametral compression test following the ASTM C158 standard in a universal testing machine (1000 kN Emic). To ensure that the samples were tested under plane stress conditions, samples with dimensions of 26x3 mm (diameter $\mathrm{x}$ thickness) were used. Bubble point: the bubble point method gives information about the pores that control the permeation, and it is used to measure pores with size above $50 \mathrm{~nm}$ (ASTM F316-03). It consists of filling the porous structure of the membrane with a liquid and measuring the air pressure necessary to displace the liquid inside the pores. The minimum pressure necessary to blow the first observed air bubble corresponds to the largest pore size of the membrane; this value is known as the bubble point [43, 44]. The mathematical relationship between pressure and pore size is given by the Washburn equation:

$$
\Delta \mathrm{P}=\frac{4 \cdot \gamma \cdot \cos \phi}{\mathrm{Dp}}
$$

where $\Delta \mathrm{P}$ is the pressure drop (bar), $\mathrm{Dp}$ is the pore size $(\mu \mathrm{m}), \phi$ is the contact angle between the fluid and pore walls, and $\gamma$ is the liquid surface tension (isopropyl alcohol). In order to be able to use the Washburn equation, the pores are assumed to be cylindrical. To reduce surface tension and facilitate measurement, liquids with low surface tension are used, such as alcohol. The scheme of the bubble point experimental equipment is presented in Fig. 1.

Separation experiments of oil-in-water emulsion: Fig. 2 shows the system used in the process of separation of oil/ water emulsion. For the tests, oil/water emulsions were produced with a concentration of $100 \mathrm{mg} . \mathrm{L}^{-1}$. Oily wastewater was prepared emulsifying lubricant mineral oil (Lubrax, Petrobras, SL SAE 20W/50 API SL) in distilled water under stirring (high-speed stirrer) for 20 min to produce a stable emulsion. The concentration of oil present in the aqueous phase was determined by the analysis of absorbance using a spectrophotometer (UV-visible, UV-1800, Shimadzu). A

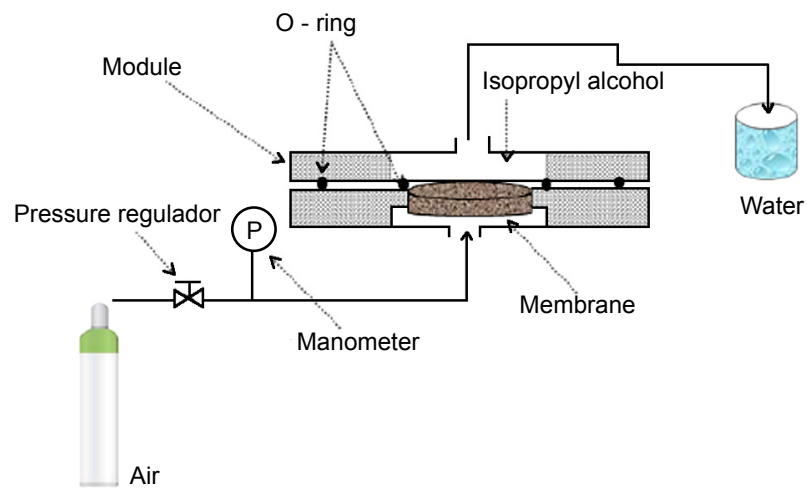

Figure 1: Scheme of the bubble point experimental equipment: 1) gas cylinder; 2) pressure regulator; 3) pressure gauge; 4) membrane; 5) module; 6) O-ring; 7) isopropyl alcohol; and 8) tank. [Figura 1: Esquema do equipamento experimental do ponto de bolha: 1) cilindro de gás; 2) regulador de pressão; 3) manômetro; 4) membrana; 5) módulo; 6) O-ring; 7) álcool isopropílico; e 8) tanque.]

calibration curve of absorbance versus concentration using different concentrations of oil ranging from 0 to $100 \mathrm{mg} . \mathrm{L}^{-1}$ was built with a coefficient of determination $\left(\mathrm{R}^{2}\right)$ of 0.9963 . Chloroform was used as a solvent for extraction because of an excellent response (significant peak) at a wavelength of $262 \mathrm{~nm}$ for the samples analyzed. The absorbance at this wavelength is commonly used to estimate the concentration of oil in water samples and also in produced water. Bands of aromatic $\mathrm{CH}$ in the medium are measured at this wavelength. Based on this, the absorbance was measured at this wavelength. This procedure was designed to normalize the determination of oil and grease contents [45]. The permeate flux was calculated by dividing the permeate volume by the product of the membrane area and the sampling time. The oil retention coefficient $\mathrm{R}$ was calculated as a percentage according to:

$$
\mathrm{R}=\frac{\mathrm{C}_{\mathrm{f}}-\mathrm{C}_{\mathrm{p}}}{\mathrm{C}_{\mathrm{f}}} \cdot 100
$$

where $\mathrm{C}_{\mathrm{f}}$ is the oil concentration in the feed, and $\mathrm{C}_{\mathrm{p}}$ is the oil concentration in the permeate. Flow membrane operation was used in the filtration experiments with the apparatus shown in Fig. 2. The membrane disk was sealed with a pair of O-rings in the homemade stainless steel membrane housing. Water flux measurements: Fig. 2 presents the system used for measurements of pure water flux through the membranes of gamma-alumina and composite $\mathrm{NaA}$ zeolite/gammaalumina as a function of time. A flat sheet membrane module made of stainless steel was used in the two experiments. The effective area of the membrane in the module was 0.22 $\mathrm{m}^{2}$. Experiments were carried out at a pressure of $1.5 \mathrm{bar}$, at $27^{\circ} \mathrm{C}$, during $60 \mathrm{~min}$, and the flux was calculated by:

$$
\text { Flux }=\frac{\mathrm{Q}}{\text { A.t }}
$$

where $\mathrm{Q}$ is the quantity of permeate $\left(\mathrm{m}^{3}\right), \mathrm{A}$ is the effective membrane area $\left(\mathrm{m}^{2}\right)$, and $\mathrm{t}$ is the sampling time $(\mathrm{h})$. 


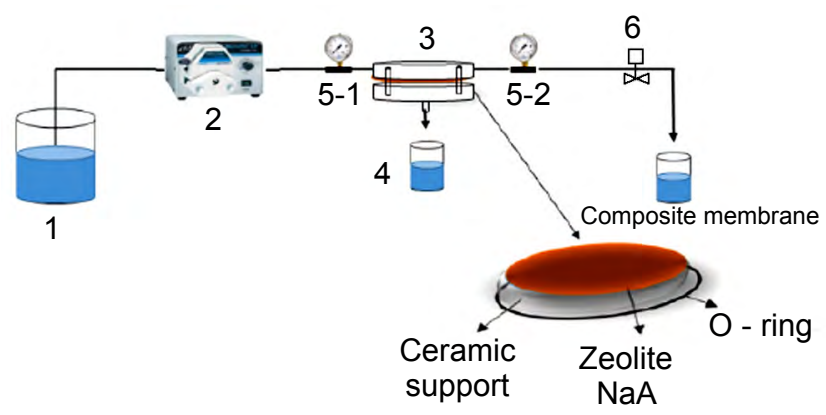

Figure 2: System used for flux measurements: 1) feed tank; 2) peristaltic pump; 3 ) permeation/separation module (stainless steel); 4) permeated volume; 5-1) pressure gauge before module input; 5-2) pressure gauge after module input; and 6) pressure regulator (concentrate).

[Figura 2: Sistema utilizado para medições de fluxo: 1) tanque de alimentação; 2) bomba peristáltica; 3) módulo de permeação/ separação (aço inoxidável); 4) volume permeável; 5-1) manômetro antes da entrada do módulo; 5-2) manômetro após o módulo entrada; e 6) regulador de pressão (concentrado)].

\section{RESULTS AND DISCUSSION}

Powders: the $\mathrm{N}_{2}$ adsorption-desorption isotherm of the gamma-alumina powder is presented in Fig. 3a, while the pore size distribution curve determined by the Barret-JoynerHatenda (BJH) model is presented in Fig. 3b. The isotherm for the sample was of type IV and exhibited a well-defined H1 hysteresis loop according to the IUPAC classification, relative to the mesoporous structure (Table I) [46]. A steep hysteresis loop can be seen in Fig. 3a, typical for mesoporous materials that exhibit capillary condensation and evaporation [47]. The existence of a large mesopore structure in this material [48] was shown by the sharp rise in the nitrogendesorption isotherms at high relative pressures $\left(\mathrm{P} / \mathrm{P}_{0}\right.$ near $0.97)$. The pore sizes of the sample were concentrated in the $5-50 \mathrm{~nm}$ range (Fig. 3b). The textural analysis of the gammaalumina is presented in Table I. According to the evaluation by the BET method, the specific surface area was $150 \mathrm{~m}^{2} / \mathrm{g}$, and the total pore volume was $0.6492 \mathrm{~cm}^{3} / \mathrm{g}$. The value of mesopore volume $\left(0.6446 \mathrm{~cm}^{3} / \mathrm{g}\right)$ was higher than the value of micropore volume $\left(0.0046 \mathrm{~cm}^{3} / \mathrm{g}\right)$. It was observed that the values of the properties of gamma-alumina were according to the literature [46]. The BET analysis also showed that the NaA zeolite (Table I) presented a specific surface area of 196 $\mathrm{m}^{2} / \mathrm{g}$ and a pore volume of $0.218 \mathrm{~cm}^{3} / \mathrm{g}$. These results were in accordance with those obtained in [33].

Membranes: the results of average pore diameter, porosity, and mechanical strength of the ceramic membrane are presented in Table II. The tensile strength of the ceramic membrane (gamma-alumina support sintered at $700{ }^{\circ} \mathrm{C}$ ) was $1.3 \mathrm{MPa}$, the average pore diameter was $0.02 \mu \mathrm{m}$, and porosity was $37.95 \%$. The tensile strength of the composite membrane (sintered at $550{ }^{\circ} \mathrm{C}$ ) was $1.0 \mathrm{MPa}$, the average pore diameter was $0.012 \mu \mathrm{m}$, and porosity was $38.94 \%$. Zeolite membranes have unique pore structures containing two types of pores: uniform subnanometer zeolitic pores
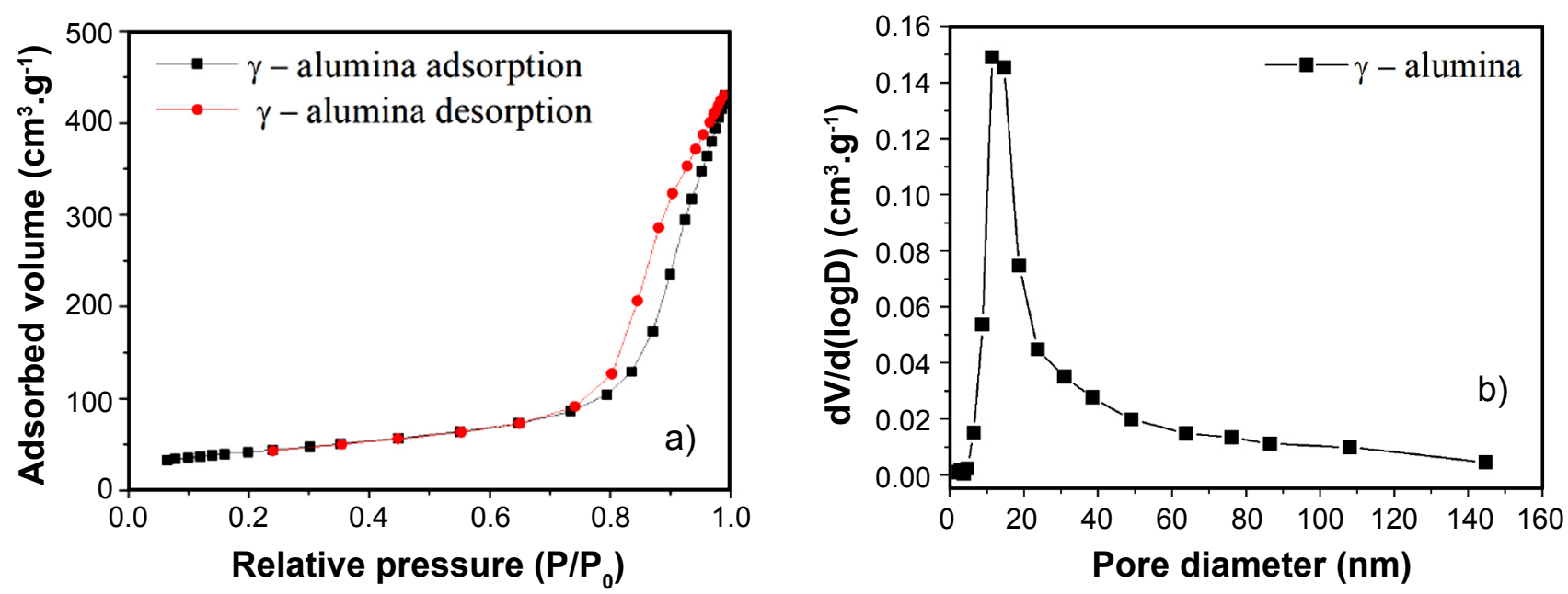

Figure 3: Nitrogen adsorption-desorption isotherm at $-196^{\circ} \mathrm{C}$ (a) and BJH pore size distribution curve (b) of gamma-alumina (powder). [Figura 3: Isoterma de adsorção-dessorção de $N_{2}$ a $-196{ }^{\circ} \mathrm{C}($ a) e curva de distribuição de tamanho de poros pelo método BJH (b) da gama-alumina (pó).]

Table I - Results of textural analysis of gamma-alumina and NaA zeolite powders. [Tabela I - Resultados da análise textural de pós de gama-alumina e zeólita NaA.]

\begin{tabular}{cccccc}
\hline Sample & $\mathrm{S}_{\mathrm{BET}}\left(\mathrm{m}^{2} / \mathrm{g}\right)$ & $\mathrm{V}_{\mathrm{P}}\left(\mathrm{cm}^{3} / \mathrm{g}\right)$ & $\mathrm{V}_{\text {Micro }}\left(\mathrm{cm}^{3} / \mathrm{g}\right)$ & $\mathrm{V}_{\text {Meso }}\left(\mathrm{cm}^{3} / \mathrm{g}\right)$ & $\mathrm{D}_{\mathrm{P}}^{\#}(\mathrm{~nm})$ \\
\hline Gamma-alumina & 150 & 0.6492 & 0.0046 & 0.6446 & 20.00 \\
NaA zeolite & 196 & 0.2180 & - & - & 3.23 \\
\hline
\end{tabular}

\# - pore size derived from the desorption isotherm determined by the BJH method. 
Table II - Average pore diameter, porosity, and mechanical strength of ceramic and composite membranes.

[Tabela II - Diâmetro médio dos poros, porosidade e resistência mecânica das membranas cerâmica e compósita.]

\begin{tabular}{ccccc}
\hline Membrane & $\begin{array}{c}\text { Sintering } \\
\text { temperature }\left({ }^{\circ} \mathrm{C}\right)\end{array}$ & $\begin{array}{c}\text { Average pore } \\
\text { diameter }(\mu \mathrm{m})\end{array}$ & $\begin{array}{c}\text { Porosity } \\
(\%)\end{array}$ & $\begin{array}{c}\text { Mechanical strength } \\
(\mathrm{MPa})\end{array}$ \\
\hline Ceramic & 700 & 0.020 & 37.95 & 1.3 \\
Composite & 550 & 0.012 & 38.94 & 1.0 \\
\hline
\end{tabular}

and inter-crystal micropores with certain size distribution $[49,50]$. Water is expected to transport across both the interparticle pores and the intra-particle pores [26].

Bubble point: the bubble point measurement was performed to estimate the average pore size of the membranes developed herein. This method only provides one measure of the largest active pore of a given membrane. In Table III the pore diameter values calculated from Eq. A are presented at certain pressures using isopropyl alcohol as the impregnating liquid. The composite membrane of $\mathrm{NaA}$ required relatively much higher pressure to expel the first bubble, confirming the presence of resistance in accordance with XRD and SEM characterizations. In the case of asymmetric membranes, the measurement of pore size distribution by intrusion mercury porosimetry or bubble point would not reflect the size of the pores controlling the flow. Another limitation in the case of asymmetric membranes is the inability of this method to distinguish between the pores that determine the flux and the largest pores in the support [51].

Table III - Results of bubble point test of ceramic and composite (NaA zeolite/gamma-alumina) membranes.

[Tabela III - Resultados de teste de ponto de bolha de membranas cerâmica e compósita (zeólita NaA/aluminagama).]

\begin{tabular}{ccc}
\hline Membrane & Ceramic & Composite \\
\hline$\Delta \mathrm{P}($ bar $)$ & 0.500 & 1.000 \\
$\mathrm{Dp}(\mu \mathrm{m})$ & 1.664 & 0.832 \\
\hline
\end{tabular}

$X$-ray diffraction: the results of NaA zeolite, gammaalumina, and composite membrane are presented in Fig. 4. The diffractogram of the zeolite NaA (Fig. 4a) presented a typical profile for the $\mathrm{NaA}$ zeolite structure, with main peaks at $2 \theta$ of $7.17^{\circ}, 10.28^{\circ}, 12.78^{\circ}, 16.26^{\circ}$, and $47.3^{\circ}$ characterizing the crystalline phase of the NaA zeolite, with no other secondary phases identified (according to the International Center for Diffraction Data, JCPDS 430168), characteristics of crystalline and pure materials. This showed that the synthesis method conditions employed in this research were effective for the production of the $\mathrm{NaA}$ zeolite [42]. From the XRD pattern shown in Fig. 4b, it is possible to observe the characteristics and well-resolved peaks of the gamma-alumina phase. After calcination at $700{ }^{\circ} \mathrm{C}$ for $2 \mathrm{~h}$, peaks at $2 \theta$ of $19^{\circ}, 32-45^{\circ}$, and $60-67^{\circ}$ were observed, indicating that the precursor was converted to gamma-alumina (JCPDS 10-0425). Fig. 4c shows the XRD pattern of the composite membrane (NaA zeolite/ gamma-alumina). It was possible to identify two distinct phases as the constituents of the composite membrane structure: NaA zeolite and gamma-alumina. The diffraction peaks presented by the membrane revealed the existence of crystalline structures with well-defined peaks, indicating high crystallinity.

Scanning electron microscopy: SEM images of the surfaces of the NaA zeolite, ceramic membrane, and composite membrane are shown in Fig. 5. It can be seen in the micrograph of the NaA zeolite (Fig. 5a) particles with morphology consisting of cubic symmetry distributed

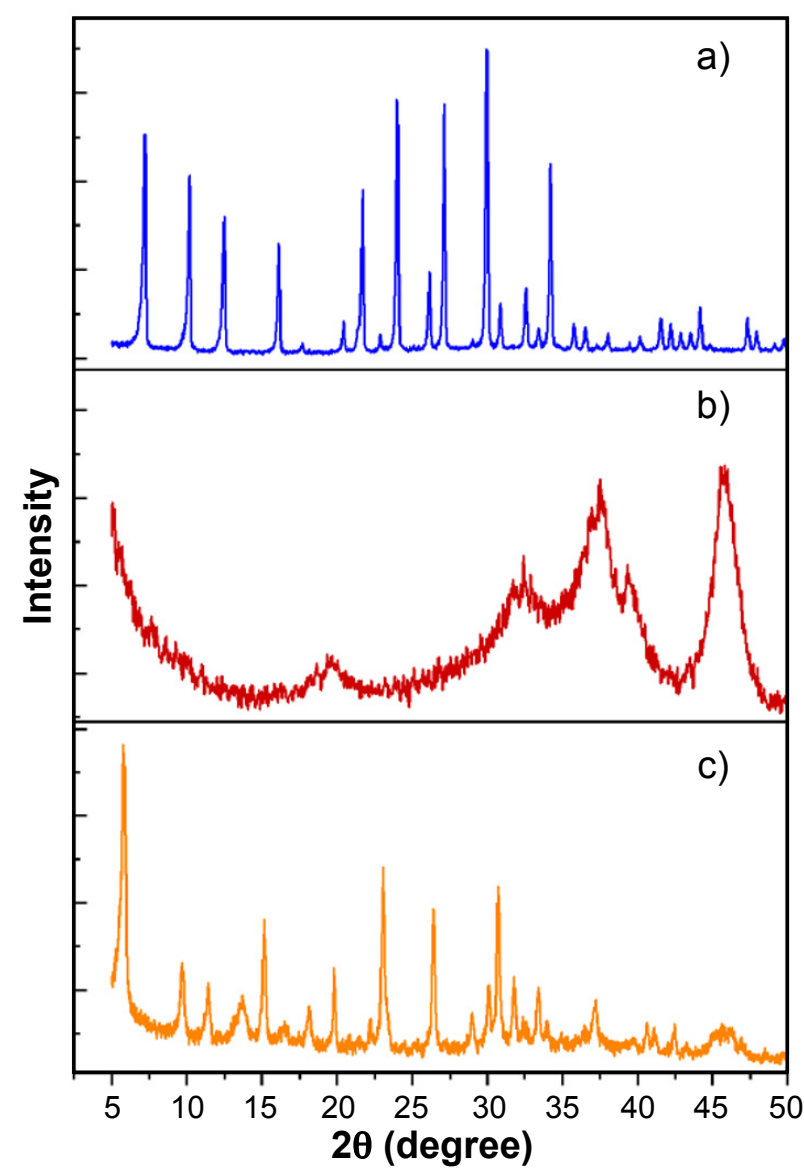

Figure 4: XRD patterns of: a) NaA zeolite (powder); b) gammaalumina; and c) composite membrane.

[Figura 4: Padrões de DRX de: a) zeólita NaA (pó); b) gamaalumina; e c) membrana compósita.] 

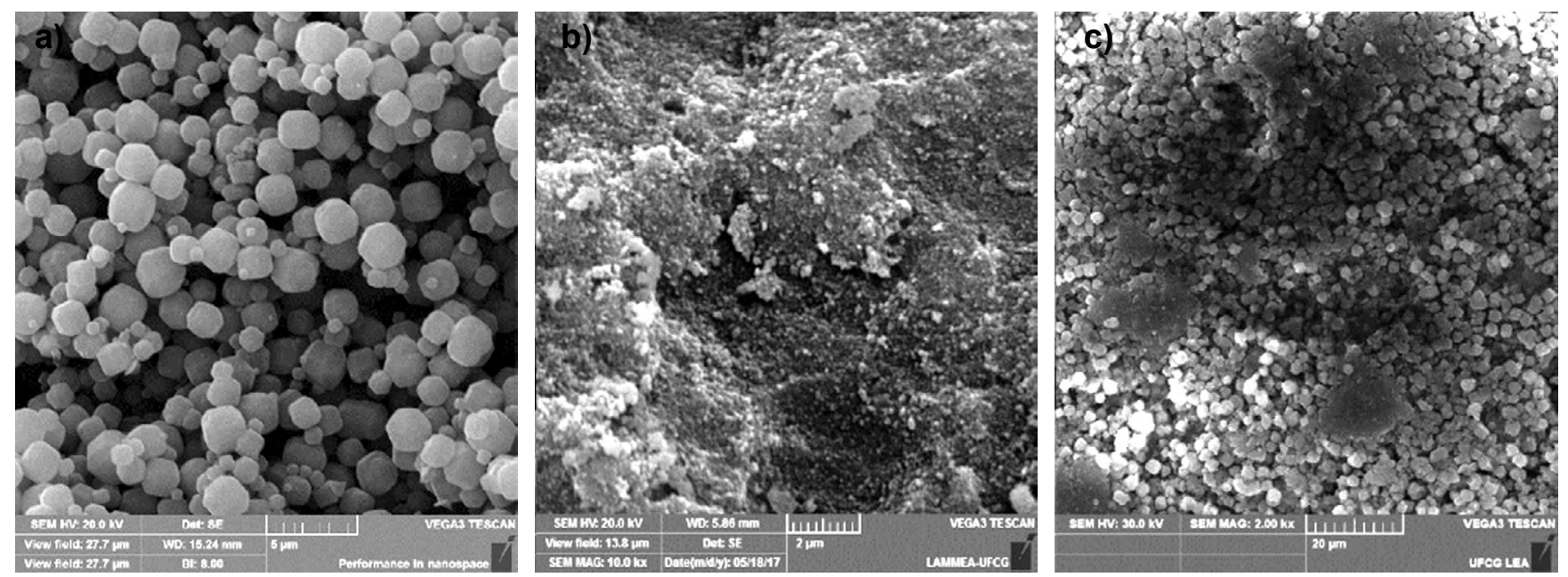

Figure 5: SEM images of: a) NaA zeolite (powder); b) ceramic membrane; and c) composite membrane.

[Figura 5: Imagens de MEV de: a) zeólita NaA (pó); b) membrana cerâmica; e c) membrana compósita.]

uniformly, besides having flat faces, with intergrowth of cubic crystals, which are characteristics of the $\mathrm{NaA}$

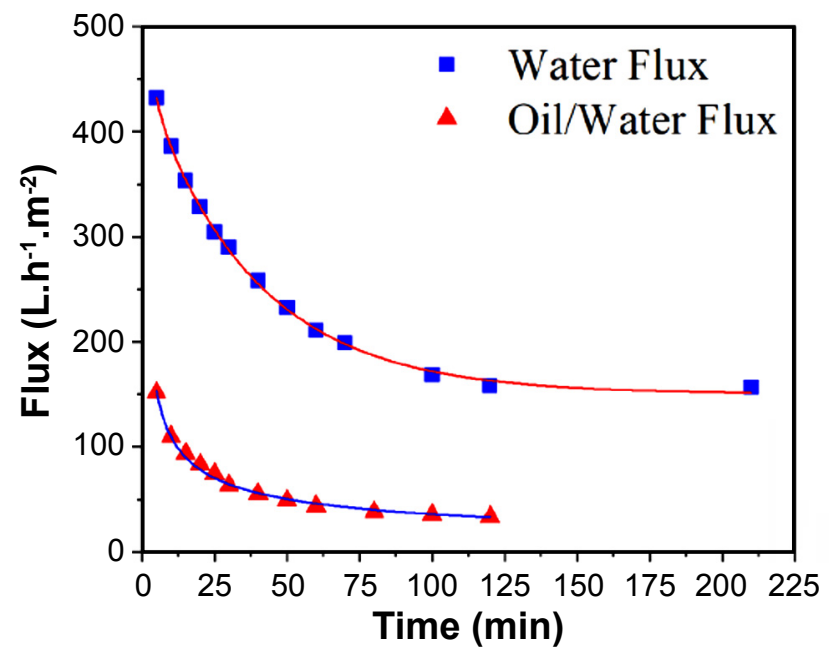

Figure 6: Pure water flux measurements and removal of oil-water emulsion as a function of time for the composite membrane. Experimental conditions were $2.0 \mathrm{bar}, 25^{\circ} \mathrm{C}$, running time $=210$ and $120 \mathrm{~min}, \mathrm{pH}$ oil-water emulsion $=6$.

[Figura 6: Medições de fluxo de água pura e remoção da emulsão óleolágua em função do tempo para a membrana compósita. As condições experimentais foram 2,0 bar, $25^{\circ} \mathrm{C}$, tempo de execução $=210$ e $120 \mathrm{~min}, \mathrm{pH}$ da emulsão $=6$. zeolite structure [51]. The micrograph in Fig. 5b (ceramic membrane sintered at $700^{\circ} \mathrm{C}$ ) clearly shows that there were no cracks. It was seen that the obtained gamma-alumina exhibited the plate-like morphology, many plates overlapped and interconnected with each other, and had some residual pores with different sizes [51]. The reason that led to this phenomenon suggests that pore structures were occupied by water during the sintering process. In the SEM image of Fig. $5 \mathrm{c}$, it can be seen two distinct crystals as the constituents of the composite membrane structure: NaA zeolite and gammaalumina.

Pure water flux measurements and separation experiments of oil-in-water emulsion: pure water permeation experiments are one of the essential procedures for determining the structure of prepared membranes. Pure water flux is affected by the membrane structure (porosity) and afterward by preparation variables [9]. The water flux through the composite membrane was evaluated using pure water as a permeate. Fig. 6 also illustrates the flux as a function of time obtained using water-oil emulsion for the composite membrane. A typical flux-time curve of microfiltration was observed. It was seen that the flux decreased after the deposition of the top layer. This result was expected and was attributed to the addition of $\mathrm{NaA}$ zeolite to the gamma-alumina. This may be related to the characteristics of $\mathrm{NaA}$ zeolite (porosity, pore size

Table IV - Results of microfiltration of inorganic membranes used for oil-water emulsion separation.

[Tabela IV - Resultados de microfiltração de membranas inorgânicas utilizadas para separação de emulsão óleo-água.]

\begin{tabular}{|c|c|c|c|c|c|}
\hline Membrane $^{\#}$ & $\begin{array}{l}\text { Operational } \\
\text { parameters }\end{array}$ & Parameters & $\begin{array}{c}\text { Flux } \\
\left(\mathrm{L} \cdot \mathrm{m}^{-2} \cdot \mathrm{h}^{-1}\right)\end{array}$ & $\begin{array}{l}\text { Rejection } \\
\text { efficiency } \\
(\%)\end{array}$ & Ref. \\
\hline NaA/gamma-alumina & $2.0 \mathrm{bar}, 25^{\circ} \mathrm{C}$ & $\begin{array}{c}\text { Synthetic oil wastewater, } \\
\mathrm{C}_{\mathrm{f}}=100 \mathrm{mg} \cdot \mathrm{L}^{-1}, \mathrm{C}_{\mathrm{p}}=2.2 \mathrm{mg} \cdot \mathrm{L}^{-1}\end{array}$ & 150 & 97.8 & $\begin{array}{l}\text { This } \\
\text { study }\end{array}$ \\
\hline ZSM-5/gamma-alumina & $\begin{array}{l}\text { Atmospheric } \\
\text { pressure, } 25^{\circ} \mathrm{C}\end{array}$ & Wastewater, $C_{\mathrm{f}}=600 \mathrm{mg} \cdot \mathrm{L}^{-1}$ & 264 & 91.3 & {$[30]$} \\
\hline
\end{tabular}

\# - both membranes were prepared by the mechanical mixing method 
distribution, and hydrophilicity), which is characterized as small-pore zeolite with a cubic structure. This zeolite is highly hydrophilic and has a low $\mathrm{Si} / \mathrm{Al}$ ratio [52]. Also, it was noted that the composite membrane had a flux of $450 \mathrm{~L} \cdot \mathrm{h}^{-1} \cdot \mathrm{m}^{-2}$ at 2 bar. Physical properties such as pore size and its distribution throughout the membrane are key to separation performance [53]. Particle size distribution is a significant material characteristic in the preparation of an asymmetric membrane because it is precisely associated with porosity and pore size [54]. Zeolite NaA is widely used to separate polar from non-polar molecules by permeation because it is extremely hydrophilic due to its low $\mathrm{Si} / \mathrm{Al}$ ratio. Due to its hydrophilic nature and relative ease of preparation, the $\mathrm{NaA}$ zeolite membrane is of special interest for the selective separation of hydrophilic/ hydrophobic liquid mixtures [24].

The permeate volume was measured continuously during the process using the composite membrane. The membrane was used to separate contaminated water (100 mg. $\mathrm{L}^{-1}$ theoretical). As shown in Fig. 6, the performed tests indicated a gradual decline of the oil concentration in the feed, similar to what has been noted in the literature [30]. This showed that the flux of the oil/water emulsion through the membrane became lower in the course of time. This decrease in flux through the membrane is observed in the literature because the particles of oil are deposited on the membrane surface or in its pores. This problem can be solved with frequent cleaning or can be reduced depending on the type of pretreatment used for the residue $[30,55]$. Under these conditions, the pressure exerted upon the oil droplets is considerably higher than the repelling force of the hydrophilic surface. The oil droplets penetrate through the ceramic membrane pores by deformation, resulting in an increase in the oil concentration in the filtrate.

Based on the oil separation test, the composite membrane was efficient, removing up to $97.8 \%$ of the oil. Similar results were found in [30], using zeolite ZSM-5/ gamma-alumina membranes and evaluating them for oil/ water separation, under the same conditions, except for the atmospheric pressure and the ZSM-5 zeolite utilized. The oil/water removal using this composite membrane showed high oil retention (91.3\%). However, it was noted that the composite NaA/gamma-alumina membrane (present study) removed more than the composite ZSM5/gamma-alumina membrane [30]. This fact can be explained by two factors: i) different zeolite structures; and ii) different pressure. Results of the performance of other inorganic microfiltration membranes used for the oil-water emulsion separation are shown in Table IV. In comparison with the results found in the literature, the results of the composite membrane produced in this study were satisfactory [30]. Since the technique used to obtain the composite membrane was the mechanical mixing of two materials (NaA zeolite and gammaalumina), the membrane thickness was very large. This fact may explain the low water flow $\left(150 \mathrm{~L} \cdot \mathrm{m}^{-2} \cdot \mathrm{h}^{-1}\right)$.

\section{CONCLUSIONS}

The effect of the insertion of the NaA zeolite to gammaalumina membrane was investigated, determining permeate flux and oil removal efficiency. The performance of the membrane for the separation of the oil-in-water emulsion was excellent. The permeate concentrations were less than that allowed for the disposal according to the specifications of the Brazilian legislation, CONAMA/2007, which determines the maximum oil content in the water for disposal of $29 \mathrm{mg} / \mathrm{L}$.

\section{ACKNOWLEDGMENT}

The authors gratefully acknowledge CAPES (Coordenação de Aperfeiçoamento de Pessoal de Nível Superior).

\section{REFERENCES}

[1] A. Al-Futaisi, A. Jamrah, B. Yaghi, R. Taha, J. Hazard. Mater. 141 (2007) 557.

[2] G. Chen, G. He, Sep. Purif. Technol. 31 (2003) 83.

[3] A. Fakhru'l-Razi, A. Pendashteh, L.C. Abdullah, D.R.A. Biak, S.S. Madaeni, Z.Z. Abidin, J. Hazard. Mater. 170 (2009) 530 .

[4] M. Reed, S. Johnsen (Eds.), "Produced water 2: environmental issues and mitigation technologies", Plenum Publ., New York (1996).

[5] R. Sandarea, "Comprehensive assessment of world crude oil supply through 2030”, Penn En. Res. Center, Oklahoma (2012).

[6] B.R. Hansen, S.R. Davies, Chem. Eng. Res. Des. 72 (1994) 176.

[7] K.S. Ashaghi, M. Ebrahimi, P. Czermak, Open Environ. Sci. 1 (2007) 1.

[8] B.H. Diya'uddeen, W.M.A.W. Daud, A.R.A. Aziz, Process Saf. Environ. Prot. 89 (2011) 95.

[9] H.P. Hsieh, Inorganic membranes for separation and reaction 3, Elsevier Sci., Amsterdam (1996).

[10] A.J. Burggraaf, L. Cot (Eds.), "Fundamentals of inorganic membrane science and technology" 4, Elsevier Sci., Amsterdam (1996).

[11] L. Cot, A. Ayral, J. Durand, C. Guizard, N. Hovnanian, A. Julbe, A. Larbot, Solid State Sci. 2 (2000) 313.

[12] S.P. Nunes, Membr. Sci. Technol. 13 (2008) 121.

[13] A. Basile, C. Charcosset, Integrated membrane systems and processes, John Wiley Sons (2016).

[14] S.M. Auerbach, K.A. Carrado, P.K. Dutta (Eds.), "Handbook of zeolite science and tecnology", Marcel Dekker, New York (2003).

[15] A. Julbe, Stud. Surf. Sci. Catal. 168 (2007) 181.

[16] J. Caro, M. Noack, P. Kölsch, R. Schäfer, Micropor. Mesopor. Mater. 38 (2000) 3.

[17] J. Caro, M. Noack, Micropor. Mesopor. Mater. 115 (2008) 215.

[18] J. Caro, M. Noack, in "Advances in nanoporous 
materials" 1, S. Ernst (Ed.), Elsevier (2010) 1.

[19] J. Gascon, F. Kapteijn, B. Zornoza, V. Sebastián, C. Casado, J. Coronas, Chem. Mater. 24 (2012) 2829.

[20] Y.S. Lin, M.C. Duke, Curr. Opin. Chem. Engin. 2 (2013) 209.

[21] C. Perego, R. Bagatin, M. Tagliabue, R. Vignola, Micropor. Mesopor. Mater. 166 (2013) 37.

[22] J. Caro, in "Zeolites and zeolite-like materials", B.F. Sels, L.M. Kustov (Eds.), Elsevier, Amsterdan (2016) 283.

[23] N. Kosinov, J. Gascon, F. Kapteijn, E.J.M. Hensen, J. Membr. Sci. 499 (2016) 65.

[24] T.C. Bowen, R.D. Noble, J.L. Falconer, J. Membrane Sci. 245 (2004) 1.

[25] D.W. Breck, W.G. Eversole, R.M. Milton, T.B. Reed, T.L. Thom, J. Am. Chem. Soc. 78 (1956) 5963.

[26] J. Cui, X. Zhang, H. Liu, S. Liu, K.L. Yeung, J. Membr. Sci. 325 (2008) 420.

[27] A.P. Araújo, V.J. Silva, A.C. Crispim, R.R. Menezes, M.G.F. Rodrigues, Mater. Sci. Forum 660-661 (2010) 1058. [28] A.P. Araújo, M.G.F. Rodrigues, Av. Cien. Ing. 3 (2012) 51.

[29] A.S. Barbosa, A.S. Barbosa, M.G.F. Rodrigues, $11^{\text {th }}$ Int. Conf. Catal. Membr. React., Porto (2013).

[30] J.R. Scheibler, E.R.F. Santos, A.S. Barbosa, M.G.F. Rodrigues, Desalin. Water Treat. 26 (2015) 3561.

[31] A.S. Barbosa, A.S. Barbosa, M.G.F. Rodrigues, Mater. Sci. Forum 805 (2014) 272.

[32] A.S. Barbosa, A.S. Barbosa, M.G.F. Rodrigues, Desalin. Water Treat. 56 (2015) 3665.

[33] F.M.N. Silva, T.L.A. Barbosa, M.G.F. Rodrigues, $12^{\text {th }}$ Int. Conf. Catal. Membr. React., Szczecin (2015).

[34] F.M.N. Silva, E. G. Lima, T.L.A. Barbosa, M.G.F. Rodrigues, $13^{\text {th }}$ Int. Conf. Catal. Membr. React., Houston (2017).

[35] R.S. Souza Cunha, J.D. Mota, M.F. Mota, M.G.F. Rodrigues, F. Machado, Mater. Sci. Forum 912 (2018) 263.

[36] A.S. Barbosa, A.S. Barbosa, T.L.A. Barbosa, M.G.F. Rodrigues, $13^{\text {th }}$ Int. Conf. Catal. Membr. React., Houston
(2017).

[37] A.S. Barbosa, A.S. Barbosa, M.G.F. Rodrigues, Mater. Sci. Forum 912 (2018) 12.

[38] A.S. Barbosa, A.S. Barbosa, T.L.A. Barbosa, M.G.F. Rodrigues, Sep. Purif. Technol. 200 (2018) 141.

[39] A.S. Barbosa, A.S. Barbosa, M.G.F. Rodrigues, Mater. Sci. Forum 958 (2019) 23.

[40] Y. Zhan, S. He, X. Wan, S. Zhao, Y. Bai, J. Membr. Sci. 567 (2018) 76.

[41] X. Yang, Y. He, G. Zeng, X. Chen, H. Shi, D. Qing, F. Li, Q. Chen, Chem. Eng. J. 321 (2017) 245.

[42] R.W. Thompson, M.J. Huber, J. Cryst. Growth 56 (1982) 711.

[43] E. Jakobs, W.J. Koros, J. Membr. Sci. 124 (1997) 149.

[44] ISO 4003, "Permeable sintered metal materials: determination of bubble test pore size" (1977).

[45] S.B. Henderson, S.J.W. Grigson, P. Johnson, B.D. Roddie, Mar. Pollut. Bull. 38 (1999) 1141.

[46] G. Busca, in "Advances in catalysis" 57, F.C. Jentoft (Ed.), Elsevier, Amsterdan (2014) 319.

[47] S.J. Gregg, K.S.W. Sing, Adsorption, surface area and porosity, $2^{\text {nd }}$ ed., Academic Press, New York (1982).

[48] H. Zhu, D.J. Jones, J. Zajac, R. Dutartre, M. Rhomari, J. Rozière, Chem. Mater. 14 (2002) 4886.

[49] M. Kazemimoghadam, Desalination 251 (2010) 176. [50] L. Xing-Dong, W. Yi-Pin, C. Xue-Mim, H. Yan, M. Jin, Powder Technol. 243 (2013) 184.

[51] P.A. Badkar, J.E. Bailey, J. Mater. Sci. 11 (1976) 1794.

[52] W. Zhu, L. Gora, A.W.C. Van den Berg, F. Kapteijn, J.C. Jansen, J.A. Moulijn, J. Membr. Sci. 253 (2005) 57.

[53] F. Li, Y. Yang, Y. Fan, W. Xing, Y. Wang, J. Membr. Sci. 397-398 (2012) 17.

[54] L. De Angelis, M.M.F. Cortalezzi, Sep. Purif. Technol. 118 (2013) 762.

[55] S. Rezaei, M.R. Abadi, M.R. Sebzari, M. Hemati, F. Rekabdar, T. Mohammadi, Desalination 265 (2011) 222.

(Rec. 25/06/2019, Rev. 08/10/2019, 21/11/2019, Ac. 24/11/2019) 